\title{
Marlena Ciechan-Kujawa
}

Uniwersytet Mikołaja Kopernika w Toruniu

e-mail: marlenac@umk.pl

\section{Karolina Sychta}

Uniwersytet Mikołaja Kopernika w Toruniu

e-mail: karolinasychta94@gmil.com

\section{RACHUNEK KOSZTÓW CYKLU ŻYCIA PRODUKTU W PRAKTYCE POLSKICH PRZEDSIĘBIORSTW \\ COST ACCOUNTING OF PRODUCT LIFE CYCLE IN THE PRACTICE OF POLISH ENTERPRISES}

DOI: 10.15611/pn.2018.514.09

JEL Classification: M11, M31, M41

Streszczenie: Celem artykułu jest prezentacja wyników badania ankietowego dotyczącego zastosowania rachunku kosztów cyklu życia produktu w polskich przedsiębiorstwach produkcyjnych. W ramach badania zidentyfikowano czynniki wpływające na długość cyklu życia produktów oraz metody identyfikacji poszczególnych faz cyklu życia, mające zastosowanie w różnych branżach. Ustalono zakres rachunku kosztów, w tym rodzaje kosztów uwzględnianych w poszczególnych fazach, oraz kompleksowość procesu zarządzania nimi. Analiza wykazała, że znajomość metod identyfikacji faz cyklu życia jest bardzo zróżnicowana, jednak najczęściej jednostki stosują metody wymagające najmniejszych nakładów pracy. Zaobserwowano również zjawisko nieuwzględniania w rachunku kosztów wszystkich rodzajów kosztów ponoszonych w cyklu. Bardzo często w analizach całkowicie pomijane są koszty fazy poprodukcyjnej.

Słowa kluczowe: rachunek kosztów, cykl życia produktu, zarządzanie kosztami, kalkulacja kosztów.

Summary: The aim of the article is to present the survey results relating to the use of life cycle cost accounting in Polish production companies. Within the survey factors affecting product life cycle length and methods of identifying several life cycle phases applicable in various industries were identified. The scope of functioning of cost accounting was established, including the types of costs taken into account in each phase and the comprehensiveness of the process of managing them. The analysis demonstrated that the command of methods of identifying the phases of the life cycle is very diverse but generally entities use methods that require the least amount of work. There was also the phenomenon of not taking into account the costs of all types of costs incurred in the cycle. Very often in the analysis, the costs of the post-production phase are completely ignored.

Keywords: cost accounting, product life cycle, cost management, cost calculation. 


\section{Wstęp}

Koncepcja cyklu życia, stanowiąca element teorii zmian, opisuje dynamikę rozwoju produktu, podkreślając zjawisko jego względnej nietrwałości w zmieniającym się otoczeniu. Cykl życia rozumiany jest tu jako ciąg zmian zachodzących od koncepcji produktu aż do śmierci. Zazwyczaj wyodrębnianych jest kilka jego kluczowych etapów: projektowanie i rozwój, wprowadzenie, wzrost, dojrzałość i schyłek, ale dla potrzeb analizy czy syntezy naukowej stosowane są też inne podziały.

Cykl życia produktu może być rozpatrywany z różnych punktów widzenia. Najpowszechniejsza jest marketingowa koncepcja cyklu życia, obejmująca fazy od wprowadzenia wyrobu na rynek do momentu jego wycofania. Skupia się ona na zarządzaniu sprzedażą produktu [Sojak 2015, s. 66]. Wyróżnia się także podejście produkcyjne i konsumenckie. Podejście produkcyjne rozróżnia trzy etapy cyklu życia: przedprodukcyjny, produkcyjny i poprodukcyjny, natomiast podejście konsumenckie rozpatruje cykl życia produktu z perspektywy klienta, dla którego rozpoczyna się on w chwili zakupu, a kończy w momencie zaprzestania użytkowania produktu, co wiąże się z likwidacją.

Podział cyklu życia produktu na fazy ma charakter umowny, a długość i przebieg poszczególnych faz zależy m.in. od specyfiki branży i strategii rozwoju jednostki. Łuczak [2005, s. 138] podkreśla znaczenie takich czynników jak: wrażliwość na zmiany koniunkturalne, rodzaj zaspokajanych potrzeb, postęp techniczny, sezonowość, moda, a Taranko [2011, s. 203] wskazuje także na możliwości różnicowania produktu, nadawania mu nowych właściwości oraz podatność produktu na zmiany preferencji kupujących. Przebieg kolejnych faz uzależniony jest też od uwarunkowań środowiskowych i ekonomicznych, dlatego wykres cyklu życia produktu jest indywidualny dla każdego wyrobu. Poszczególne fazy cyklu życia produktu różnią się rodzajem i wysokością ponoszonych w nich kosztów i osiąganych przychodów. Dlatego przy ocenie opłacalności wprowadzania produktu na rynek należy uwzględniać skumulowane koszty i przychody występujące we wszystkich fazach cyklu życia produktu na rynku. Szeroki przegląd literatury przeprowadzony przez Kambanou i Lindahl [2016] wskazuje, że publikacje dotyczące przedmiotowego zagadnienia mają w większości charakter studiów teoretycznych i omawiają modele kosztów, metody, ramy, zarządzanie ryzykiem i niepewnością, rzadkością natomiast są badania empiryczne lub prezentacja przypadków.

Celem artykułu jest prezentacja wyników badania, których zamierzeniem była diagnoza metod identyfikacji faz cyklu życia stosowanych w praktyce gospodarczej oraz ustalenie kompleksowości funkcjonującego rachunku kosztów cyklu życia produktu w przedsiębiorstwach produkcyjnych. Założono, że przedsiębiorstwa stosują proste metody identyfikacji faz cyklu życia oraz nie uwzględniają w analizach wszystkich rodzajów kosztów ponoszonych w poszczególnych fazach cyklu życia produktu. W pierwszej części artykułu przedstawiono wyniki badań dotyczące cyklu życia produktu, czynników wpływających na jego długość oraz metody diagnozy poszczególnych faz tego cyklu. W dalszej części scharakteryzowano funkcjono- 
wanie rachunku kosztów cyklu życia w badanych jednostkach, zwłaszcza zakres identyfikowanych kosztów i proces zarządzania nimi. Ostatnia część opracowania dotyczy obszarów wykorzystania rachunku cyklu życia oraz barier jego rozwoju w badanych przedsiębiorstwach.

\section{Metodyka badania i opis próby badawczej}

Badanie zostało przeprowadzone na przełomie kwietnia i maja 2017 r. metoda CAWI. O udział w badaniu zwrócono się do 316 przedsiębiorstw produkcyjnych ${ }^{1}$, działających w takich branżach jak: budownictwo, przemysł chemiczny i kosmetyczny, przemysł spożywczy, przemysł odzieżowy i obuwniczy, przy czym tylko $25 \mathrm{z}$ nich zadeklarowało zarządzanie kosztami w cyklu życia produktu i wypełniło kwestionariusz ankietowy. Do badania wybrano przedsiębiorstwa produkcyjne, zakładając potencjalnie większe ich zainteresowanie problematyką skutecznego zarządzania kosztami produktu w cyklu jego życia, chociaż należy podkreślić, że zarządzanie cyklem życia produktów może mieć zastosowanie we wszystkich rozmiarach przedsiębiorstw i różnych sektorach (od przemysłowych, po dystrybucję i usługi), a także w jednostkach edukacyjnych czy organizacjach rządowych [Stark 2015]. Próba badawcza ograniczona została do czterech branż w celu przedstawienia na podstawie otrzymanych wyników podstawowych różnic i podobieństw między przedsiębiorstwami różnych sektorów. W badaniu wzięły udział przedsiębiorstwa długo funkcjonujące na rynku, różnej wielkości, w zdecydowanej większości z kapitałem polskim. Najliczniej była reprezentowana branża budowlana. Szczegółową charakterystykę badanych podmiotów zaprezentowano w tabeli 1.

Tabela 1. Charakterystyka badanych jednostek

\begin{tabular}{|c|c|c|}
\hline \multirow{2}{*}{ Wyszczególnienie } & \multicolumn{2}{|c|}{ Udział } \\
\hline & liczba & $\%$ \\
\hline 1 & 2 & 3 \\
\hline Ogółem & 25 & 100 \\
\hline \multicolumn{3}{|c|}{ Branża } \\
\hline Budownictwo & 12 & 48 \\
\hline Artykuły spożywcze & 4 & 16 \\
\hline Chemia/kosmetyki & 6 & 24 \\
\hline Odzież/obuwie & 3 & 12 \\
\hline \multicolumn{3}{|c|}{ Długość funkcjonowania na rynku } \\
\hline Poniżej 5 lat & 1 & 4 \\
\hline 5-10 lat & 0 & 0 \\
\hline 11-20 lat & 5 & 20 \\
\hline 21-50 lat & 14 & 56 \\
\hline Powyżej 50 lat & 5 & 20 \\
\hline
\end{tabular}

1 Bazę przedsiębiorstw do badania pozyskano ze strony internetowej: http://wszystkocopolskie. blogspot.com/p/lista-polskich-firm.html. 
Tabela 1, cd.

\begin{tabular}{|l|r|c|}
\hline \multicolumn{1}{|c|}{1} & 2 & 3 \\
\hline \multicolumn{1}{|c|}{ Wielkość zatrudnienia } & 16 \\
\hline Poniżej 50 pracowników & 4 & 40 \\
\hline 50-250 pracowników & 10 & 24 \\
\hline 250-500 pracowników & 5 & 20 \\
\hline Powyżej 500 pracowników & 5 & \\
\hline
\end{tabular}

Źródło: badanie ankietowe.

\section{Cykl życia produktu i jego determinanty}

Badanie obejmowało analizę cyklu życia produktu, w tym czynników wpływających na jego długość oraz metod identyfikacji poszczególnych faz. Na podstawie odpowiedzi można stwierdzić, że największy wpływ na wielkość sprzedaży i kształt krzywej cyklu życia danego produktu mają konsumenci. W grupie analizowanych podmiotów jako najistotniejszy czynnik jednoznacznie wskazywano zmiany zachowań i gustów konsumentów (rys. 1), a w dalszej kolejności: postęp technologiczny, sezonowość oraz modę. Analizując odpowiedzi, można również zauważyć, że poza pierwszym z wymienionych, pozostałe wskazania różnią się w zależności od reprezentowanego przez respondentów sektora. Przedstawiciele branży budowlanej wskazywali na postęp technologiczny jako czynnik o istotnym wpływie, a firmy przemysłu spożywczego na sezonowość oraz modę. Wpływ sezonowości podkreślany był również przez przedstawicieli przedsiębiorstw przemysłu chemicznego i kosmetycznego, a znaczenie mody przez spółki odzieżowe czy obuwnicze. Najmniejsze znaczenie zdaniem respondentów mają: wrażliwość produktów na zmiany koniunkturalne i wpływ uwarunkowań środowiskowych.

wrażliwość na zmiany koniunkturalne uwarunkowania środowiskowe postęp technologiczny sezonowość moda zachowania i gusty konsumentów rodzaj zaspakajanych potrzeb inne

0

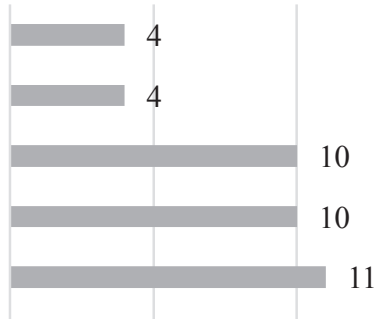

1

7

0

5

10

15

20

Rys. 1. Czynniki wpływające na długość cyklu życia produktu

Źródło: badanie ankietowe. 
Odpowiedzi na pytanie o długość cyklu życia wiodących produktów przedsiębiorstwa były zdecydowanie bardziej zróżnicowane. Mimo że przedstawiciele badanych jednostek najczęściej wskazywali na długi cykl życia ich produktów, powyżej 10 lat, to krótsze cykle, trwające kilka miesięcy czy tygodni, również były wybierane. Przy czym należy zaznaczyć, że opinie respondentów były przede wszystkim zależne od reprezentowanej przez nich branży. Długie cykle życia typowali dominujący w badaniu przedstawiciele branży budowlanej i przemysłu chemicznego/ kosmetycznego. W tych sektorach cykl życia produktu trwa nie krócej niż 2 lata, a często nawet powyżej 10 lat. Pozostali respondenci, należący do sektora przemysłu spożywczego, odzieżowego lub obuwniczego, wskazywali na cykle życia produktów w ich branży nieprzekraczające 2 lat.

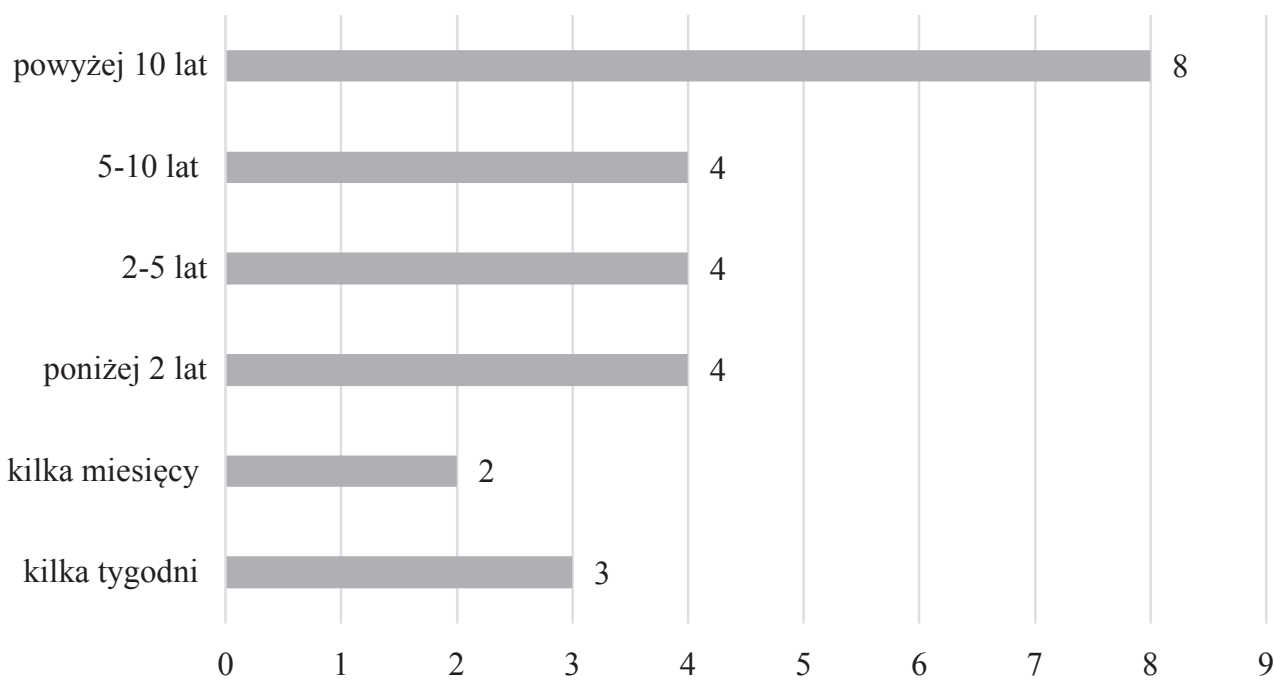

Rys. 2. Długość cyklu życia kluczowego produktu wytwarzanego przez przedsiębiorstwa Źródło: badanie ankietowe.

Z badania wynika, że przedsiębiorstwa przywiązują największą wagę do zarządzania produktem w początkowych fazach jego cyklu życia (rys. 3). Większość respondentów identyfikuje fazy wprowadzenia na rynek oraz wzrostu sprzedaży. Fazą, której firmy poświęcają najmniejszą uwagę, jest faza dojrzałości produktu.

Proces identyfikacji poszczególnych faz realizowany jest zazwyczaj przy użyciu najprostszej metody, opartej wyłącznie na analizie wielkości przychodów ze sprzedaży produktu (rys. 4). Oznacza to, że dla przedsiębiorstw najistotniejszą informacją o pozycji danego produktu na rynku jest wolumen przychodów, który on generuje. Podmioty niechętnie stosują bardziej skomplikowane metody szacowania faz, wymagające dodatkowych obliczeń, pomiarów i badań rynku. Spośród podanych metod respondenci mogli wybrać wszystkie właściwe odpowiedzi lub wskazać inne 
faza wprowadzenia na rynek

faza wzrostu sprzedaży

faza dojrzałości produktu/faza nasycenia rynku

$$
\text { faza spadku sprzedaży }
$$

żadna z powyższych
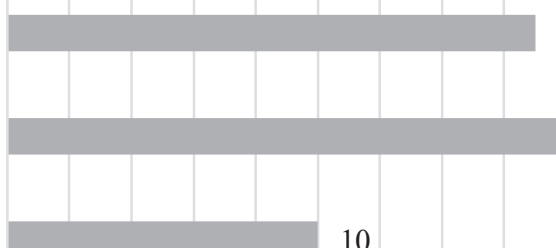

10

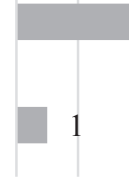

$\begin{array}{llllllllll}0 & 2 & 4 & 6 & 8 & 10 & 12 & 14 & 16 & 18\end{array}$

Rys. 3. Fazy cyklu życia produktu identyfikowane w przedsiębiorstwach

Źródło: badanie ankietowe.

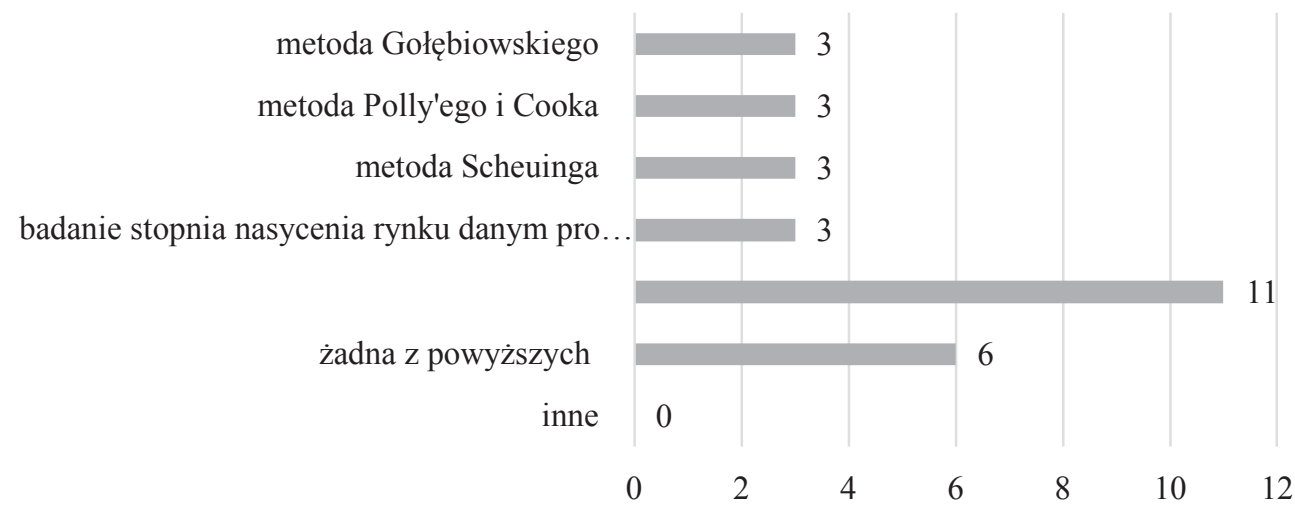

Rys. 4. Metody identyfikacji faz cyklu życia produktu stosowane przez przedsiębiorstwa

Źródło: badanie ankietowe.

stosowane metody, jednak pozostałe metody uzyskały zaledwie po 3 wskazania. Najbardziej pracochłonne metody identyfikacji - metodę Polly'ego i Cooka oraz metodę Scheuinga - wykorzystują duże, długo funkcjonujące na rynku podmioty. Należy zauważyć, że ta grupa przedsiębiorstw również kompleksowo zarządza kosztami, planując je w cyklu życia produktu, poddając monitorowaniu i kontroli. Wyniki badań dowodzą, że jedna czwarta $\mathrm{z}$ badanych przedsiębiorstw nie stosuje żadnych metod identyfikacji faz cyklu życia. 


\section{Koszty cyklu życia}

Rozważając cykl życia produktu od strony kosztowej, można wyodrębnić dwie perspektywy: klienta i producenta. Jaruga i in. [2010, s. 620] podkreślają, że w koncepcji konsumenckiej najważniejszą miarą jest zdolność produktu do zaspokojenia potrzeb, a ceną za posiadanie produktu przez klienta jest nie tylko cena nabycia, lecz także koszty utrzymania, koszty napraw i likwidacji oraz w niektórych przypadkach wycofanie wyrobu z użytkowania. Rachunek kosztów cyklu życia z perspektywy producenta powinien obejmować koszty ponoszone od momentu rozpoczęcia badań nad produktem do wycofania go z rynku, z uwzględnieniem - co podkreśla Norris [2001, s. 20] - kosztów bezpośrednich, pośrednich, warunkowych, niematerialnych i zewnętrznych. W pierwszej fazie cyklu przedmiotem zarządzania są zatem koszty badań i rozwoju. Chalastra [2015, s. 18] zwraca uwagę, że w okresie przedprodukcyjnym koszty dotyczą przyszłych okresów i powinny być rozliczone w czasie poprzez rozliczenia międzyokresowe kosztów lub amortyzację. Po wprowadzeniu produktu na rynek identyfikacji, planowaniu, monitorowaniu i kontroli powinny podlegać zarówno koszty wytwarzania produktu, jak i koszty wsparcia procesu produkcyjnego, logistyki czy dystrybucji produktów. W końcowej fazie cyklu życia istotna jest analiza kosztów zakończenia produkcji i wycofania wyrobu z rynku. Te ostatnie dotyczą głównie zaniechania produkcji, likwidacji, ochrony środowiska i reklamacji. Przeglądu modeli analizy kosztów dokonali m.in. Durairaj, Ong, Nee, Tan [2002], porównując następujące podejścia: model of Fabrycky and Blanchard, model of Woodward, model of Dahlen and Bolmsjo, Activity Based Costing, Economic Input-Output LCA model, Design to Cost Model, PLCCA to Manufacturing System, Total Cost Assessment (TCA) Model.

Na podstawie badań można potwierdzić zdecydowanie mniejsze zainteresowanie przedsiębiorstw identyfikacją i zarządzaniem kosztami faz przed- i poprodukcyjnej. W obu przypadkach zarówno liczba wskazań respondentów, jak i zakres identyfikowanych kosztów jest mniejszy (tab. 2).

W pierwszej fazie cyklu życia przedsiębiorstwa szczególną wagę przywiązują do identyfikacji kosztów badań i rozwoju, najmniejszą zaś do kosztów testowania. Dwóch respondentów nie uwzględnia żadnych kosztów fazy przedprodukcyjnej. W ramach fazy produkcyjnej można zauważyć głównie zainteresowanie zarządzaniem kosztami bezpośrednimi, tj. kosztami zużycia materiałów i energii oraz wynagrodzeń pracowników produkcyjnych. Najrzadziej w tej grupie kosztów wskazywano na zarządzanie kosztami kontroli jakości. Należy zwrócić uwagę, że wszystkie przedsiębiorstwa wskazały na uwzględnianie w analizie cyklu życia produktu wybranych kategorii kosztów charakterystycznych dla tej fazy. Wśród kosztów identyfikowanych $\mathrm{w}$ fazie poprodukcyjnej najwięcej jednostek analizuje koszty napraw gwarancyjnych. Niemniej jest to tylko jedna trzecia badanych. Tyle samo jednostek deklarowało, że nie uwzględnia w rachunku kosztów żadnych kosztów charakterystycznych dla tej fazy cyklu życia produktu. W grupie tej znaleźli się przedstawi- 
ciele wszystkich czterech branż. Spółki, które udzieliły takiej odpowiedzi, należały w zdecydowanej większości do średniej wielkości dojrzałych firm, działających na rynku ponad 20, a nawet 50 lat. Ponadto przedsiębiorstwa te w pytaniu o metodę identyfikacji faz zaznaczały przeważnie metodę najprostszą, opartą na badaniu wyłącznie przychodów ze sprzedaży. Nie można zatem stwierdzić, że wraz ze wzrostem stażu rynkowego oraz rozwojem mającym odzwierciedlenie w zwiększaniu zatrudnienia przedsiębiorstwa zwiększają zakres analizowanych kosztów. Przeczą temu zwłaszcza wyniki badań w zakresie zarządzania kosztami fazy poprodukcyjnej.

Tabela 2. Koszty fazy przedprodukcyjnej, produkcyjnej i poprodukcyjnej uwzględniane w rachunku kosztów cyklu życia

\begin{tabular}{|c|c|c|}
\hline Faza cyklu życia & Rodzaj kosztu & $\begin{array}{c}\text { Liczba } \\
\text { wskazań }\end{array}$ \\
\hline \multirow[t]{6}{*}{ Przedprodukcyjna } & koszty badań i rozwoju danego produktu & 17 \\
\hline & koszty związane z organizacją miejsca produkcji & 13 \\
\hline & koszty projektowania produktu & 11 \\
\hline & koszty testowania produktu & 8 \\
\hline & żadne z kosztów przedprodukcyjnych & 2 \\
\hline & inne koszty fazy przedprodukcyjnej & 0 \\
\hline \multirow[t]{8}{*}{ Produkcyjna } & koszty zużycia materiałów i energii & 20 \\
\hline & koszty serwisowania maszyn & 14 \\
\hline & koszty wynagrodzeń pracowników produkcyjnych & 17 \\
\hline & koszty dystrybucji & 12 \\
\hline & koszty kontroli jakości & 10 \\
\hline & koszty reklamy & 12 \\
\hline & \begin{tabular}{|l|} 
żadne z kosztów produkcyjnych \\
\end{tabular} & 0 \\
\hline & inne koszty fazy produkcyjnej & 0 \\
\hline \multirow[t]{6}{*}{ Poprodukcyjna } & koszty napraw gwarancyjnych & 11 \\
\hline & koszty likwidacji & 4 \\
\hline & koszty recyklingu & 5 \\
\hline & koszty dywestycji (ograniczenia zakresu i skali działalności) & 3 \\
\hline & żadne z kosztów poprodukcyjnych & 10 \\
\hline & inne koszty fazy poprodukcyjnej & 2 \\
\hline
\end{tabular}

Źródło: badanie ankietowe.

Na podstawie analizy zakresu zarządzania kosztami cyklu życia przedstawionej na rysunku 5 można natomiast wnioskować, że w jednostkach, które identyfikują poszczególne kategorie kosztów, zarządzanie nimi ma charakter kompleksowy. Prawie $70 \%$ badanych planuje przedmiotowe koszty, a ponad połowa monitoruje na bieżąco ich poziom i kontroluje odchylenia od planu (por. rys. 5). Szczegółowa analiza dowodzi jednak, że kompleksowo zarządza kosztami w cyklu życia (planuje, monitoruje i kontroluje ich poziom) tylko $9 \mathrm{z}$ badanych przedsiębiorstw. Głównie są 
to średnie i duże jednostki długo funkcjonujące (najczęściej 21-50 lat), spoza branży budowlanej. Przedsiębiorstwa budowlane deklarowały zazwyczaj tylko planowanie kosztów (5 wskazań).

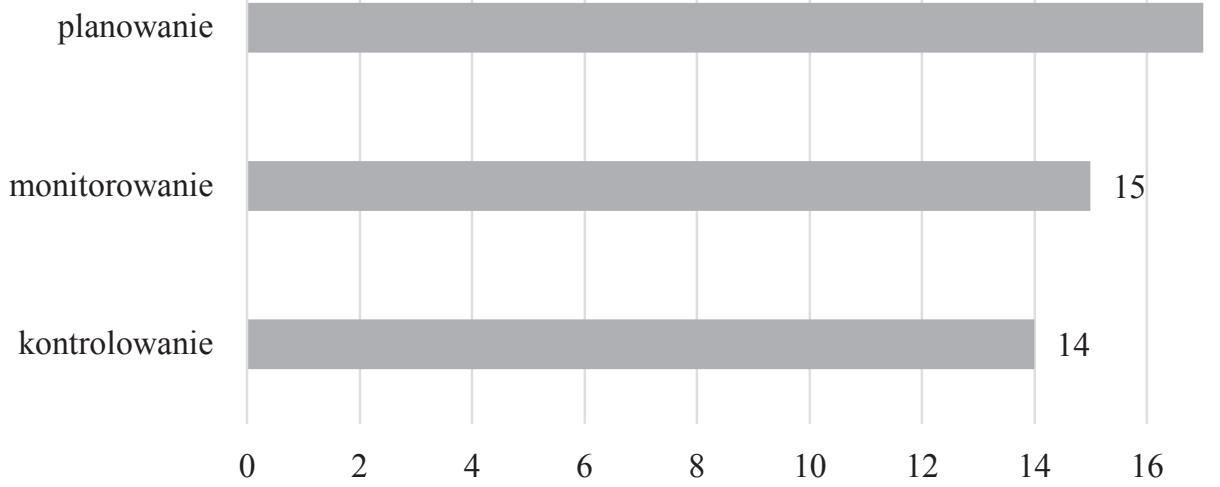

Rys. 5. Zarządzanie kosztami cyklu życia produktu

Źródło: badanie ankietowe.

\section{Obszary wykorzystania rachunku cyklu życia}

Rachunek cyklu życia znajduje zastosowanie w realizowaniu celów strategicznych i operacyjnych. Wśród podstawowych celów strategicznych Łada [2017, s. 19] wymienia: poszukiwanie inwestorów mogących sfinansować nową ofertę produktową, usprawnianie projektowania nowych produktów oraz rozwój długookresowych relacji z klientami. W obszarze operacyjnym należy zwrócić uwagę na użyteczność tego narzędzia $\mathrm{w}$ prowadzeniu bieżącej polityki sprzedaży, analizie współpracy z zewnętrznymi partnerami oraz podejmowaniu decyzji o zakupach. Ponadto w literaturze podkreślana jest istotność rachunku kosztów cyklu życia w porównywaniu konkurencyjnych projektów pod względem rentowności w całym cyklu życia oraz wykorzystanie informacji $\mathrm{z}$ analiz prowadzonych $\mathrm{w}$ tym zakresie $\mathrm{w}$ procesie budżetowania długoterminowego, zwłaszcza dla ustalenia wysokości środków potrzebnych na pokrycie przyszłych wydatków [Norris 2001, s. 18-20]. Stosowanie rachunku cyklu życia pozwala również określić relacje z dostawcami i odbiorcami poprzez porównanie ofert, ustalenie przyczyn odchyleń między planem a wykonaniem w kolejnych fazach. Kowalak [2009, s. 43] zwraca uwagę na możliwość wykorzystania tego narzędzia w logistyce w celu porównania koncepcji logistycznych, a w efekcie optymalizacji procesów oraz uniknięcia „wąskich gardeł”.

Wyniki badań, przedstawione na rysunku 6, pokazują, że w przedsiębiorstwach rachunek kosztów cyklu życia produktu służy głównie określaniu odpowiedniej po- 
lityki cenowej i marketingowej oraz znajduje zastosowanie w ocenie rentowności produktów w długim okresie, a także w procesie budżetowania i planowania długoterminowego. Pozostałe wymieniane w literaturze obszary zastosowań tego narzędzia są wykorzystywane rzadko. Należy jednak zaznaczyć, że tylko dwóch respondentów wskazało brak jego przydatności w podejmowaniu decyzji zarządczych.

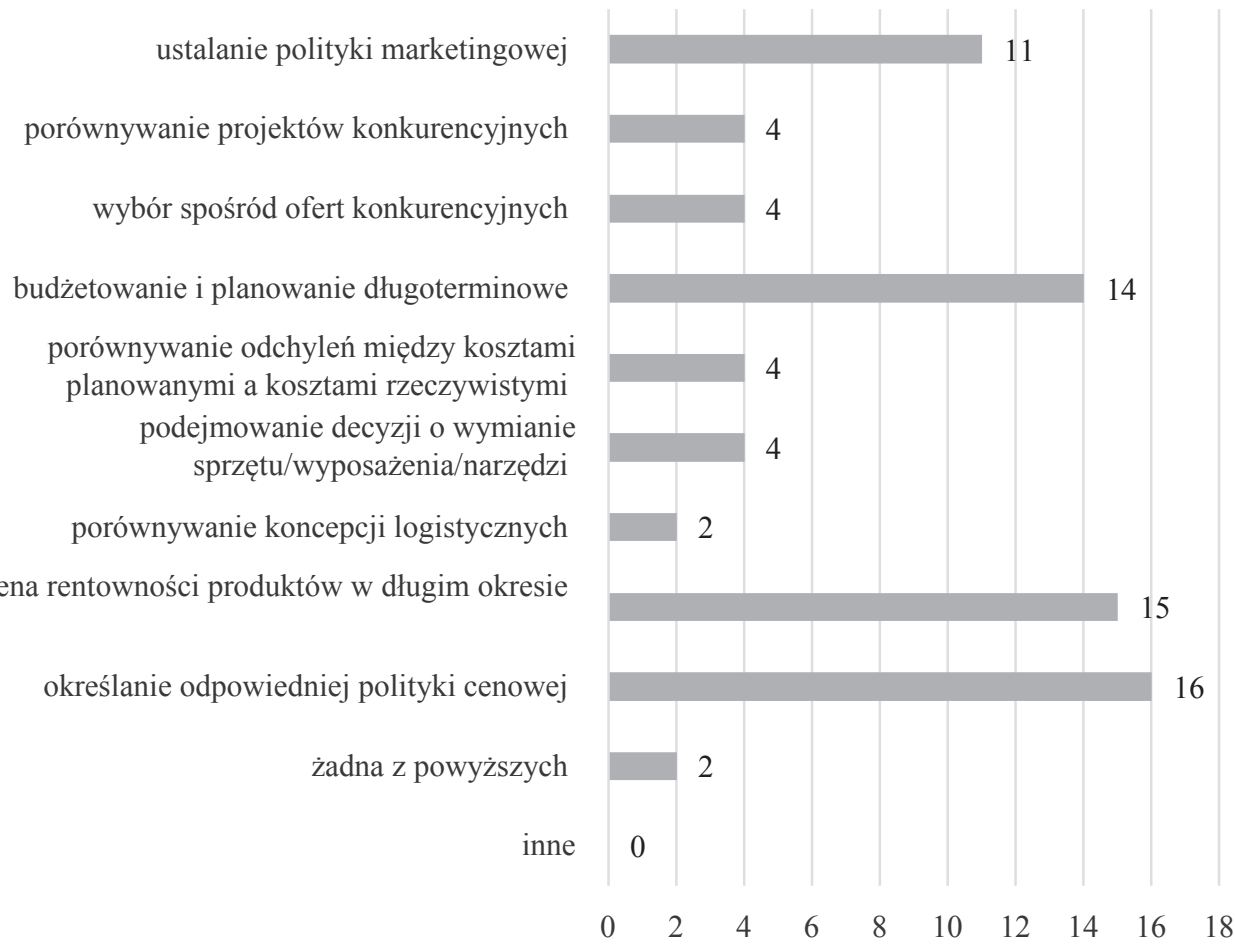

Rys. 6. Zastosowanie rachunku kosztów cyklu życia produktu

Źródło: badanie ankietowe.

\section{Bariery zastosowania i rozwoju rachunku cyklu życia}

Przedstawiciele badanych przedsiębiorstw wskazują, że największe trudności związane z kompleksowym wdrożeniem rachunku kosztów cyklu życia produktu wynikają z braku odpowiednich kompetencji w ich organizacjach. Zdaniem aż dwóch trzecich ankietowanych podstawową barierą jest konieczność posiadania rozległej wiedzy w wielu obszarach, w tym finansach i rachunkowości, inżynierii produkcji logistyce, marketingu. Wiąże się z zaangażowaniem specjalistów, a brak ich dostępności na rynku stanowi kolejną barierę rozwoju tego narzędzia, podkreślaną głównie przez jednostki funkcjonujące na rynku 21-50 lat. 
Na problemy w poprawnym i precyzyjnym określeniu przebiegu lub długości poszczególnych faz zwróciło uwagę aż $10 \mathrm{z}$ badanych przedsiębiorstw (por. rys. 7). Właśnie z tego powodu koncepcję cyklu życia skrytykowali Dhalla i Yuspetha, którzy stwierdzili problemy z przewidywaniem momentu wystąpienia kolejnej fazy, jej długości oraz wolumenu sprzedaży osiągniętego przez dany wyrób. Prognozowanie w ramach cyklu życia utrudniają również kształty krzywych cyklu życia oraz długości faz, które są różne dla poszczególnych produktów [Kowalak 2009, s. 65]. Błędnie oszacowana faza, w której znajduje się produkt, lub stosowanie wzorców innych produktów może przysporzyć trudności w praktycznym zastosowaniu rachunku kosztów cyklu życia.

konieczność posiadania rozległej wiedzy w wielu obszarach

konieczność posiadania wyspecjalizowanej kadry wysokie koszty wdrożenia rachunku kosztów cyklu życia błędne lub nieprecyzyjne określenie przebiegu lub długości faz cyklu życia

pracochłonność i czasochłonność stosowania rachunku kosztów cyklu życia inne

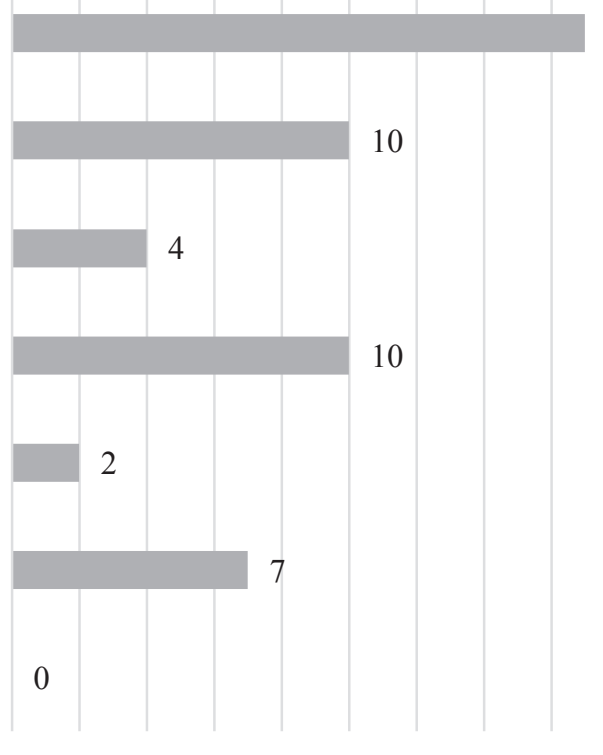

Rys. 7. Trudności związane ze stosowaniem rachunku kosztów cyklu życia Źródło: badanie ankietowe.

Dwa przedsiębiorstwa budowlane wskazały dodatkowo na problemy metodyczne związane $\mathrm{z}$ uwzględnieniem ryzyka i zmian wartości pieniądza w czasie w zarządzaniu kosztami cyklu życia produktu. Z uwagi na to, że cykl życia obejmuje długi okres, analiza jego rentowności powinna być przeprowadzana za pomocą mechanizmu dyskontowania danych. W rachunku cyklu życia konieczne jest zatem obliczenie wartości bieżącej na podstawie oszacowanych w kolejnych fazach wielkości ekonomicznych takich jak: przychody, koszty, przepływy pieniężne, a szacunki te powinny uwzględniać ryzyko zmian takich parametrów jak: cena i wielkość sprzedaży, ceny surowców, pracochłonność, wydajność czy koszty sprzedaży a także 
opcje zmniejszenia czy zwiększenia działalności [por. Ciechan-Kujawa i in. 2017, 35-38, 48; Chalastra 2015, s. 19]. Jednak to, jak skutecznie zarządzać wpływem niepewności na szacowanie kosztów, jest jednym z najczęstszych problemów poruszanych w literaturze [Kambanou, Lindahl 2016]. Ograniczeniem rachunku cyklu życia jest również jego nieskuteczność w warunkach wysokiej inflacji [Biernacki 2011, s. 40-41].

\section{Zakończenie}

Przeprowadzone badania wykazały, że rachunek kosztów cyklu życia nie jest narzędziem stosowanym powszechnie i kompleksowo. Zaobserwowano zjawisko nieuwzględniania w rachunku kosztów wszystkich rodzajów kosztów ponoszonych w cyklu. Przedsiębiorstwa najwięcej uwagi poświęcają pomiarom i analizie kosztów ponoszonych w fazie produkcyjnej, a następnie kosztów ponoszonych w fazie przedprodukcyjnej. Najmniej istotne i często pomijane są koszty ponoszone w fazie poprodukcyjnej. Wyniki te są potwierdzeniem badań innych autorów. Brak koncentracji organizacji na końcowym etapie życia produktu i związanych z nim kosztach zaobserwowali m.in. Kambanou i Lindahl [2016, s. 190].

Przedsiębiorstwa wykazują w zróżnicowanym stopniu znajomość metod identyfikacji faz cyklu życia i najczęściej stosują metody proste, wymagające najmniejszych nakładów pracy. Brak specjalistycznej wiedzy na temat metod identyfikacji, szacowania, analizy i optymalizacji kosztów w cyklu życia podkreślają również ankietowani, wskazując go jako podstawową barierę rozwoju tego narzędzia w organizacji.

\section{Literatura}

Biernacki M., 2011, Rachunek kosztów cyklu życia-ujęcie definicyjne i obszarowe, [w:] E. Nowak, M. Nieplowicz (red.), Rachunek kosztów i pomiar dokonań, Prace Naukowe Uniwersytetu Ekonomicznego we Wrocławiu, nr 182, Wydawnictwo Uniwersytetu Ekonomicznego we Wrocławiu, Wrocław, s. 36-45.

Ciechan-Kujawa M., Garstecki D., Golej R., 2017, Ocena efektywności inwestycji tradycyjnych i innowacyjnych. Metody, uwarunkowania, dylematy, Texter, Warszawa.

Chalastra M., 2015, Rachunek cyklu życia produktu, Controlling i Zarządzanie, nr 3, s. 17-22.

Durairaj S.K., Ong S.K., Nee A.Y.C., Tan R.B.H., 2002, Evaluation of Life Cycle Cost Analysis Methodologies, Corporate Environmental Strategy, vol. 9, issue 1, s. 30-39.

http://wszystkocopolskie.blogspot.com/p/lista-polskich-firm.html (14.03.2018)

Jaruga A.A., Kabalski P., Szychta A. (red.), 2010, Rachunkowość zarządcza, Wolters Kluwer Polska sp. z o.o., Warszawa.

Kambanou M.L., Lindahl M., 2016, A Literature Review of Life Cycle Costing in the Product-Service System Context, Procedia CIRP, vol. 47, s. 186-191. 
Kowalak (red.), 2009, Rachunek kosztów cyklu życia produktu w zarządzaniu przedsiębiorstwem, Wydawnictwo Uniwersytetu Ekonomicznego we Wrocławiu, Wrocław.

Łada M., 2017, Rachunek cyklu życia produktu jako narzędzie analizy rentowności, Rachunkowość, nr 11, s. 17-26.

Łuczak M., 2005, Polityka produktu, [w:] W. Żurawik (red.), Marketing. Podstawy i kontrowersje, Wydawnictwo Uniwersytetu Gdańskiego, Gdańsk.

Norris G.A., 2001, Integrating life cycle cost analysis and LCA, The International Journal of Life Cycle Assessment, March, vol. 6, issue 2, s. 118-120.

Nowak E. (red.), 2006, Strategiczne zarządzanie kosztami, Oficyna Ekonomiczna, Kraków.

Sojak S., 2015, Rachunkowość zarządcza i rachunek kosztów, t. 2, Towarzystwo Naukowe Organizacji i Kierownictwa „Dom Organizatora”, Torun.

Stark J., 2015, Product Lifecycle Management, Product Lifecycle Management, vol. 1, Decision Engineering, Springer, Cham, s. 1-29.

Taranko T., 2011, Decyzje zwiazane z produktem i marka, [w:] L. Garbarski (red.), Marketing. Kluczowe pojęcia i praktyczne zastosowania, PWE, Warszawa. 